\title{
The emerging role of mast cell proteases in asthma
}

\author{
Gunnar Pejler ${ }^{1,2}$
}

\begin{abstract}
Affiliations:
${ }^{1}$ Dept of Medical Biochemistry and Microbiology, Uppsala University, Uppsala, Sweden.

${ }^{2}$ Dept of Anatomy, Physiology and Biochemistry, Swedish University of Agricultural Sciences, Uppsala, Sweden.
\end{abstract}

\section{Correspondence:}

Gunnar Pejler, Dept of Medical Biochemistry and Microbiology, BMC, Uppsala University, Box 582, 75123 Uppsala, Sweden.

E-mail: gunnar.pejler@imbim.uu.se

\section{@ERSpublications}

Mast cells express large amounts of proteases, including tryptase, chymase and carboxypeptidase A3. An extensive review of how these proteases impact on asthma shows that they can have both protective and detrimental functions. http://bit.ly/2Gu1Qp2

Cite this article as: Pejler G. The emerging role of mast cell proteases in asthma. Eur Respir J 2019; 54: 1900685 [https://doi.org/10.1183/13993003.00685-2019].

ABSTRACT It is now well established that mast cells (MCs) play a crucial role in asthma. This is supported by multiple lines of evidence, including both clinical studies and studies on MC-deficient mice. However, there is still only limited knowledge of the exact effector mechanism(s) by which MCs influence asthma pathology. MCs contain large amounts of secretory granules, which are filled with a variety of bioactive compounds including histamine, cytokines, lysosomal hydrolases, serglycin proteoglycans and a number of MC-restricted proteases. When MCs are activated, e.g. in response to IgE receptor crosslinking, the contents of their granules are released to the exterior and can cause a massive inflammatory reaction. The MC-restricted proteases include tryptases, chymases and carboxypeptidase A3, and these are expressed and stored at remarkably high levels. There is now emerging evidence supporting a prominent role of these enzymes in the pathology of asthma. Interestingly, however, the role of the MC-restricted proteases is multifaceted, encompassing both protective and detrimental activities. Here, the current knowledge of how the MC-restricted proteases impact on asthma is reviewed. 


\section{Introduction}

Mast cells (MCs) are immune cells derived from myeloid precursors in the bone marrow [1]. A hallmark feature of MCs is their high content of lysosome-like secretory granules, which occupy a major fraction of the $\mathrm{MC}$ cytoplasm and account for their classical strong metachromatic staining [2]. The granules contain large amounts of various pre-formed inflammatory mediators such as histamine, cytokines, growth factors, serglycin proteoglycans, lysosomal hydrolases and large amounts of various MC-restricted proteases (in the following denoted the "MC proteases") [2]. The latter encompass serine proteases of the tryptase and chymase type as well as a zinc-containing metalloprotease denoted carboxypeptidase A3 (CPA3) (figure 1) [2-5].

When MCs are activated, e.g. by antigen-mediated cross-linking of IgE bound to their high-affinity cell surface receptors (FceR1), they respond by degranulation, whereby the pre-formed granule contents are released. MC activation also leads to de novo synthesis and release of numerous additional inflammatory compounds [6].

MCs are found in most tissues of the body, but are particularly abundant at sites close to the external milieu, including the skin, tongue, gut and lung. Due to this location, it is thought that MCs can act in the first-line innate defence against foreign intruders such as bacteria and various parasites $[7,8]$, and it is also established that MCs can have a major function in the clearance of various toxins [9]. However, in addition to these beneficial activities, MCs are notorious for their detrimental impact on a number of pathological settings, including asthma and other allergic conditions [10].

An impact of MCs on asthma is supported by a large amount of documentation from both clinical and experimental studies (reviewed in [11-14]). For example, the presence of MCs and extent of MC degranulation within the airway smooth muscle cell (SMC) layer shows a strong correlation with asthma $[15,16]$ and there is also evidence that uncontrolled asthma is associated with infiltration of MCs into the lung parenchyma [17]. MCs appear to be of particular importance in the T-helper cell type 2 (Th2)-high endotype of asthma and it is noteworthy that anti-IgE therapy in mild to moderate asthmatic subjects (targeting in particular MCs and basophils) has a profound impact on type 2 markers [18]. A detrimental role of MCs in asthma is also supported by experimental approaches where MC-deficient mice have been evaluated in models of asthma, although certain features of asthma can also develop in the absence of MCs [19-21]. However, although MCs are now widely recognised as major players in asthma, it is not fully understood to what extent the different compounds secreted by MCs contribute to the pathology. Given that the MC proteases are highly expressed in MCs and are released in large quantities following MC activation [2-4], it is reasonable to assume that they account, at least partly, for the effects of MCs in asthma. Indeed, there is now a growing awareness that the MC proteases have a major impact on various features of asthma. These issues are discussed in this review.

\section{MC proteases in humans and mice}

Humans express one chymase (CMA1), which is classified as an $\alpha$-chymase (table 1). Similar to humans, mice express one $\alpha$-chymase, designated Mcpt5, but also five $\beta$-chymases: Mcpt1, Mcpt2, Mcpt4, Mcpt9 and Mcpt10 [22]. Out of the mouse chymases, Mcpt5 is the closest homologue to CMA1 in terms of amino acid sequence homology but, importantly, Mcpt4 represents the functional homologue to human chymase [23-25]. Humans express two tetrameric tryptases, $\alpha$ and $\beta$, of which $\beta$-tryptase is enzymatically active, whereas $\alpha$-tryptase lacks enzymatic activity $[26,27]$. The $\beta$-tryptases are subdivided into $\beta 1, \beta 2$ and $\beta 3$; interestingly, $\beta 2$ - and $\beta 3$-tryptase are alleles at one locus (TPSB2), whereas $\alpha$ - and $\beta 1$-tryptase are alleles at a neighbouring gene (TPSAB1) $[28,29]$. In addition to the tetrameric tryptases, human MCs express a monomeric transmembrane tryptase denoted $\gamma$-tryptase (TPSG1) [30]. Similar to humans, mouse MCs

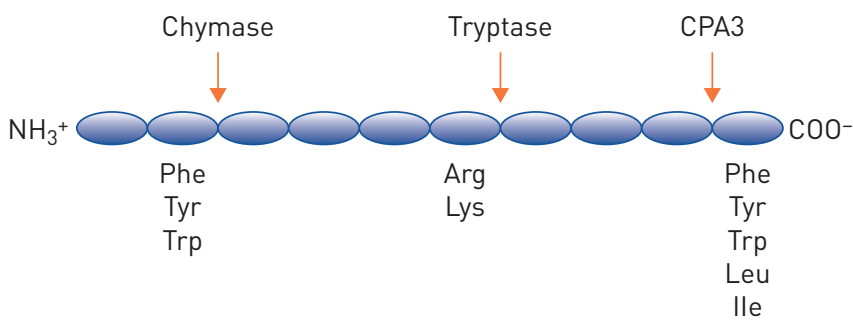

FIGURE 1 Cleavage specificities of the mast cell (MC)-restricted proteases. The figure depicts that chymase and tryptase are endopeptidases, whereas carboxypeptidase A3 (CPA3) is a C-terminal exopeptidase; chymase and CPA3 are monomeric proteases, whereas tryptase is tetrameric. The figure also depicts the substrate cleavage properties of the respective proteases, with the indicated amino acid residues representing the preferred $\mathrm{N} / \mathrm{C}$-terminal residues of the cleaved peptide bond. 


\begin{tabular}{|c|c|c|c|}
\hline Protease & Gene & Enzymatic activity & $\begin{array}{l}\text { Expression in } \\
\text { MC subtype }\end{array}$ \\
\hline \multicolumn{4}{|l|}{ Human } \\
\hline$\alpha$-tryptase & TPSAB1 & Serine protease; non-active & $\mathrm{MC}_{\mathrm{T}}+\mathrm{MC}_{\mathrm{TC}}$ \\
\hline$\beta_{1}$-tryptase & TPSAB1 & Serine protease; trypsin-like & $M C_{T}+M C_{T C}$ \\
\hline$\beta_{2}$-tryptase & TPSB2 & Serine protease; trypsin-like & $M C_{T}+M C_{T C}$ \\
\hline$\beta_{3}$-tryptase & TPSB2 & Serine protease; trypsin-like & $M C_{T}+M C_{T C}$ \\
\hline$\gamma$-tryptase & TPSG1 & Serine protease; trypsin-like & Not established \\
\hline Chymase ( $\alpha$-chymase) & CMA1 & Serine protease; chymotrypsin-like & $\mathrm{MC}_{\mathrm{TC}}$ \\
\hline Carboxypeptidase A3 & CPA3 & $\begin{array}{c}\text { Metalloprotease; } \text { C-terminal } \\
\text { exopeptidase }\end{array}$ & $\mathrm{MC}_{\mathrm{TC}}$ \\
\hline \multicolumn{4}{|c|}{ 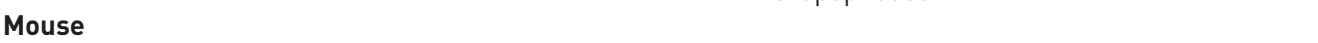 } \\
\hline Mcpt6; mMCP6 (tryptase) & Mcpt6 & Serine protease; trypsin-like & CTMC \\
\hline Mcpt7; mMCP7 ${ }^{\#}$ (tryptase) & Mcpt7 & Serine protease; trypsin-like & CTMC \\
\hline$\gamma$-tryptase & Tpsg1 & Serine protease; trypsin-like & Not established \\
\hline Mcpt1; mMCP1 ( $\beta$-chymase) & Mcpt1 & Serine protease; chymotrypsin-like & MMC \\
\hline Mcpt2; mMCP2 ( $\beta$-chymase) & Mcpt2 & Serine protease; non-active & MMC \\
\hline Mcpt4; mMCP4 ( $\beta$-chymase) & Mcpt4 & Serine protease; chymotrypsin-like & CTMC \\
\hline Mcpt5; mMCP5 ( $\alpha$-chymase) & Mcpt5/Cma1 & Serine protease; elastase-like & CTMC \\
\hline Carboxypeptidase $\mathrm{A} 3$ & Cpa3 & $\begin{array}{l}\text { Metalloprotease; } \text { C-terminal } \\
\text { exopeptidase }\end{array}$ & CTMC \\
\hline
\end{tabular}

$M C_{T}$ : $M C_{s}$ expressing tryptase only; $M C_{T C}$ : $M C$ s expressing tryptase, chymase and carboxypeptidase $A 3$; mMCP: mouse MC protease (alternative nomenclature for the mouse MC proteases); CTMC: connective tissue type MC; MMC: mucosal type MC. " : the C57BL/6 mouse strain lacks Mcpt7 expression due to a point mutation.

express two tetrameric tryptases, Mcpt6 and Mcpt7, of which Mcpt6 is thought to be the closest homologue to human $\beta$-tryptase, as well as a transmembrane $\gamma$-tryptase (Tpsg1) [5]. Notably, the C57BL/6 strain lacks Mcpt7 expression due to a point mutation. In both humans and mice, one CPA3 gene is expressed [4].

\section{MC protease phenotype in asthma}

A number of studies have characterised the protease phenotype of airway MCs in various manifestations of asthma. In healthy subjects, $\mathrm{MCs}$ expressing tryptase only $\left(\mathrm{MC}_{\mathrm{T}}\right)$ dominate over $\mathrm{MCs}$ expressing tryptase, chymase and CPA3 $\left(\mathrm{MC}_{\mathrm{TC}}\right)$ (table 1) [31]. However, there is substantial evidence that airway MCs undergo a switch in their protease phenotype in association with asthmatic disease. In particular, there is an expansion of the $\mathrm{MC}_{\mathrm{TC}}$ subtype under asthmatic conditions. This has been observed in the bronchi and airway submucosa of asthmatic subjects versus healthy controls [17, 32-34]. Furthermore, it has been shown that there is a profound increase in the population of $\mathrm{MC}_{\mathrm{TC}}$ versus $\mathrm{MC}_{\mathrm{T}}$ in the small airways of severe asthmatic subjects [35]. Studies have also revealed an increase in the $\mathrm{MC}_{\mathrm{TC}}$ subtype in the airway submucosa and epithelium of severe, but not mild, asthmatic subjects [34]. In addition, it is notable that the majority of the MCs infiltrating the SMC layer in asthma are of the $\mathrm{MC}_{\mathrm{TC}}$ subtype [15] and an increased ratio of $\mathrm{MC}_{\mathrm{TC}}$ over $\mathrm{MC}_{\mathrm{T}}$ is also supported by studies in animal models of asthma [36, 37].

As stated earlier, asthmatic disorders are strongly correlated with the appearance and/or expansion of chymase-positive MC populations of the lung, which would suggest that chymase may contribute to the pathology of asthma. However, when correlating chymase positivity with lung function parameters, studies have in fact identified a positive correlation between chymase positivity and preserved lung function. This was originally described in a study by BALzAR et al. [35], in which a positive correlation was seen between preserved lung function and presence of chymase-positive MCs in the small airways of severe asthmatic subjects. Similarly, ZANin et al. [33] reported that the density of chymase-positive MCs in bronchial biopsies from patients with mild to moderate asthma correlated positively with preserved lung function. These findings thus suggest that chymase, contrary to the overall negative impact of MCs, may serve a protective function in asthma, a notion that is also supported by studies in animal models (see the later section on "MC proteases in animal models for asthma").

Most previous investigations of MC phenotype in asthma have not included staining for CPA3 and the presence of this protease in airway MCs of healthy versus asthmatic individuals has therefore been uncertain. However, insight into this issue came from a study where CPA3 protein positivity and CPA3 gene expression were assessed in the lungs of healthy subjects and in patients with asthma stratified into 
Th2-high and Th2-low subgroups [38]. Intriguingly, it was demonstrated that MCs with a unique tryptase $^{+}$chymase ${ }^{-} \mathrm{CPA}^{+}$phenotype were prominent in the epithelium of Th2-high asthmatic subjects [38] and upregulated expression of CPA3 gene expression in epithelial MCs of asthmatic subjects has been confirmed in other studies $[34,39,40]$. This finding is thereby in some seeming contradiction with the studies showing an increase in chymase-positive MCs in asthma [15, 17, 32-34]. However, the latter studies did not specifically assess for MC protease positivity in the airway epithelium. Moreover, it is noteworthy that most of the studies on this subject have been based on the use of immunohistochemistry, and it would thus be important to confirm key findings by independent methods such as mRNA analysis and proteomic approaches.

\section{MC proteases as asthma biomarkers}

Considering the strong implication of MCs in asthma, it would appear reasonable that the MC proteases could serve as useful biomarkers to monitor asthmatic disease. This possibility has been explored in several studies focusing on measurements of serum tryptase. In one study it was shown that children with mild and moderate to severe asthma had higher serum tryptase levels in comparison with children with mild intermittent asthma and healthy controls [41]. Moreover, serum tryptase levels could be used to predict disease severity [41]. It has also been reported that serum tryptase levels in adult subjects are associated with asthma [42-44]. In contrast, RAO et al. [45] found no correlation between serum tryptase and airway responses in children with moderate to severe asthma. Furthermore, no correlation between serum tryptase and either atopy, bronchial hyperresponsiveness or symptoms of allergic respiratory disease was seen in a study on adult subjects [46], and a lack of association between serum tryptase and asthma is supported by a number of additional studies [46-50]. Collectively, there is thus some discrepancy with the regard to the association of serum tryptase with asthma. A likely explanation for this is that MC degranulation under asthmatic conditions occurs locally in the lung. Hence, tryptase levels are most likely elevated in the local environment of the lung, but not to the same extent in the circulation (as discussed in [48]). An alterative strategy could therefore be to monitor the local release of tryptase, by assessing the sputum or bronchoalveolar lavage fluid (BALF) of asthmatic subjects, and there is indeed evidence that the levels of tryptase in sputum and BALF are increased both at baseline and after airway provocation in asthmatic subjects [51-59], although contradictory findings have been reported [60, 61]. However, for practical reasons, routine analysis of tryptase in sputum/BALF is not likely to become a clinically useful method to monitor asthma. In this context it is of interest to note that interference with Th2 responses caused a decrease in the sputum levels of tryptase [62].

Another possible strategy to monitor the MC contribution in asthma could be to evaluate chymase and/or CPA3 for biomarker purposes, especially considering that asthma appears to be associated with a profound increase in MC populations positive for these proteases (see the earlier section on "MC protease phenotype in asthma"), whereas tryptase-positive populations generally do not increase. Moreover, whereas tryptase in addition to being expressed by MCs can also be expressed to some extent by other cell lineages (e.g. basophils), chymase expression appears to be strongly confined to MCs [63, 64]. A rise in chymase levels may thus reflect more closely the extent of MC degranulation than corresponding rises in tryptase levels. Monitoring of chymase and/or CPA3 could therefore have the potential to be developed as a biomarker for MC involvement in asthma. However, to date, neither chymase nor CPA3 have been evaluated for this purpose.

Furthermore, assessment of the gene expression profiles in sputum taken from asthmatic patients has identified a signature of six highly expressed genes, including $C P A 3$, that correlates positively with eosinophilic asthma [65], and can be used to predict both responsiveness to corticosteroids and future exacerbations $[66,67]$. Increased expression of CPA3 in sputum cells recovered from asthmatic subjects has been confirmed in other studies $[68,69]$. Altogether, there is thus strong correlative evidence implicating CPA3 in the manifestations of asthma, although this notion has not yet received support from experimental studies making use of selective CPA3 inhibitors or CPA3-deficient animals.

\section{MC protease gene polymorphisms in asthma}

There is so far only limited evidence suggesting a link between asthma and polymorphisms of the MC protease genes. With regard to chymase (CMA1), there is evidence that a short tandem repeat polymorphism downstream of the CMA1 gene is linked to atopic asthma [70-72]. Interestingly, no link to non-atopic asthma was found [72]. In contrast, a single nucleotide polymorphism (-1903 G/A) in the CMA1 promoter did not associate with asthma [70,73]. To date, associations between polymorphisms in any of the tryptase genes with asthma have not been reported. However, it is of interest to note that $\sim 10-40 \%$ of humans lack expression of $\alpha$-tryptase, which is predicted since $\alpha$ - and $\beta 1$-tryptase alleles compete at the TPSAB1 locus (see the earlier section on "MC proteases in humans and mice") [28, 74]. Moreover, it has been shown that a high copy number of $\alpha$-tryptase is related to a higher atopy score 
and worsened bronchial function in comparison with subjects having fewer $\alpha$-tryptase copies [75]. It has also been demonstrated that individuals harbouring a triplication of the TPSAB1 gene encoding $\alpha$-tryptase present with a multisystem disorder [76]. However, the molecular basis for the impact of the $\alpha$-tryptase allele on these conditions, especially considering that $\alpha$-tryptase is enzymatically inactive, remains to be explored.

\section{MC proteases in animal models for asthma}

An important approach to explore the role of the MC proteases in asthma has been to evaluate corresponding knockout mice in models for allergic airway inflammation. By using an ovalbumin-based model, WAERN et al. [77] showed that airway reactivity, somewhat unexpectedly (since MCs are thought to promote allergic airway inflammation), was enhanced in mice lacking the expression of the chymase Mcpt4. Moreover, it was demonstrated that airway eosinophilia was profoundly enhanced in $M c p t 4^{-1-}$ animals and that the absence of Mcpt4 led to an increase in the thickness of the SMC layer [77]. By using a model induced by repeated sensitisation with house dust mite extract, WAERN et al. [78] confirmed a protective role of chymase (Mcpt4) in airway responses [78] and it was suggested that the protective role of chymase was due to its ability to degrade interleukin (IL)-33 [78]. Further support for a protective role of chymase comes from a study where protection against allergic airway hyperresponsiveness in $\alpha_{\mathrm{v}} \beta_{6}$-integrin-deficient mice could be attributed to increased expression of Mcpt4, which inhibited IL-13-induced epithelial-dependent enhancement of contractility [79]. Importantly, since Mcpt4 represents the functional homologue to human chymase [23-25], it is likely that functions ascribed to Mcpt4 are shared by human chymase. In agreement with this notion, there is clinical evidence suggesting that human chymase can have a protective role in asthma $[33,35]$.

To study the role of tryptase in asthma, mice lacking Mcpt6 have been evaluated in an ovalbumin-based model of allergic airway inflammation. In this study it was shown that Mcpt6 contributed profoundly to the airway reactivity in methacholine-challenged animals [80]. In contrast, eosinophil infiltration and other inflammatory parameters were not affected by the absence of Mcpt6 [80]. This suggests that MC tryptase selectively affects airway narrowing, possibly by affecting SMC contraction, without contributing to tissue inflammation. However, the underlying mechanism behind this effect has not yet been revealed.

To date, animals lacking expression of CPA3 have not been evaluated in models of asthma.

In addition to studies based on knockout mice, a number of investigations have addressed the role of the MC proteases in asthma by administering recombinant/purified MC proteases in experimental systems. In an early study it was shown that administration of $\beta$-tryptase into the airways of allergic sheep caused bronchoconstriction, supporting a detrimental role for tryptase in asthma [81], and tryptase has also been demonstrated to cause constriction in isolated guinea pig and human bronchi [82, 83]. It has also been demonstrated that instillation of $\gamma$-tryptase into the trachea of mice causes airway hyperresponsiveness [84]. In agreement with a protective role for chymase in allergic lung inflammation, Sundaram et al. [85] showed that administration of recombinant chymase to human bronchial rings prevented cytokine-enhanced bronchoconstriction and it was demonstrated that such protective activity could be attributed to chymase-mediated degradation of fibronectin.

\section{Substrates for the MC proteases}

To understand the mechanism by which the MC proteases impact on asthma it is imperative to identify their proteolytic targets. Indeed, by adopting various approaches, a multitude of reports have identified substrates that could be potential targets for tryptase, chymase or CPA3 in asthma, either by experiments in purified systems, cell biological approaches or in vivo experimentation (table 2).

\section{Tryptase}

In the tryptase tetramer, all of the active sites are facing a central narrow pore, which causes restricted access for large protein substrates [86]. Accordingly, several of the identified substrates for tryptase are small peptides, including vasoactive intestinal peptide (VIP) [87, 88], calcitonin gene-related peptide (CGRP) [88] and peptide histidine-methionine [88]. However, somewhat unexpectedly, tryptase also has the ability to cleave a number larger proteins such as human/mouse fibrinogen [89, 90], gelatin (from porcine sources) [91, 92], rodent and human proteinase-activated receptor (PAR)-2 [93-95], human RANTES [96], human eotaxin-1/CCL11 [96, 97], human pro-matrix metalloproteinase (MMP) 1 [98], human/mouse pro-MMP3 [99, 100], human/mouse pro-MMP13 [100], human complement factors [101] and mouse/human histones [102]. Several of the identified tryptase substrates may be candidate proteolytic targets in the context of allergic airway inflammation. For example, VIP has recently been implicated as a potential asthma therapeutic due to its relaxing impact on SMCs [103, 104]. The degradation of VIP by tryptase could thus contribute to the detrimental impact of tryptase on asthma, a notion being supported 
TABLE 2 Substrates for the mast cell (MC) proteases

\begin{tabular}{|c|c|}
\hline \multicolumn{2}{|l|}{ Tryptase } \\
\hline VIP & Purified dog and human tryptase; purified system \\
\hline CGRP & Purified dog and human tryptase; purified system \\
\hline PHM & Purified dog and human tryptase; purified system \\
\hline Gelatine & Recombinant human $\beta$-tryptase; purified system \\
\hline Pro-MMP1, $-3,-13$ & $\begin{array}{l}\text { Tryptase added to cell-conditioned medium; data } \\
\text { from } \mathrm{Mcpt6}^{-/-} \mathrm{MCs}\end{array}$ \\
\hline PAR-2 & Cell biological approaches \\
\hline RANTES/CCL5 & $\begin{array}{c}\text { Recombinant/purified human } \beta \text {-tryptase; chemotaxis } \\
\text { assays }\end{array}$ \\
\hline Eotaxin & $\begin{array}{c}\text { Recombinant/purified human } \beta \text {-tryptase; chemotaxis } \\
\text { assays }\end{array}$ \\
\hline Histones & Cell culture, Mcpt6 ${ }^{-1-} \mathrm{MCs}$ \\
\hline Fibrinogen & $\begin{array}{c}\text { Purified } \beta \text {-tryptase; in vivo findings using } \mathrm{Mcpt6}^{-/-} \\
\text {mice }\end{array}$ \\
\hline $\begin{array}{l}\text { Complement factors } \\
\qquad(\mathrm{C} 3, \mathrm{C} 5)\end{array}$ & Purified system \\
\hline
\end{tabular}

\section{Chymase}

Fibronectin

\section{Pro-MMP2}

Pro-MMPq

Latent TGF- $\beta$

Pro-collagenase

\section{Pro-IL-1 $\beta$ \\ IL-6 \\ IL-13}

Pro-IL-18

IL-33

TNF

CCL6, CCL9, CCL15, CCL23

CTAP-III

Chemerin

Substance P

HMGB1

Thrombin

Tight junction

proteins

Big-endothelin-1

Hemidesmosomes (BP180)

Angiotensin I

VIP

\section{CPA3}

Endothelin

Neurotensin

Kinetensin

Neuromedin N

Angiotensin I
Purified systems; cell biological approaches; in vivo data from $\mathrm{Mcpt}^{-1-}$ mice

In vitro data; in vivo data from $\mathrm{Mcpt}^{-/-}$mice

In vitro data; in vivo data from $\mathrm{Mcpt4}^{-/-}$mice

Purified/recombinant human chymase; chymase inhibitor; cell biological approaches

Purified human chymase; purified system

Purified human chymase; purified system

Human purified chymase; human skin MCs

Human purified chymase; human skin MCs

Recombinant human chymase; purified systems and cell biological approach

Human chymase, purified mMCP4; purified systems and in vivo data from $\mathrm{Mcpt}^{-/-}$mice In vivo data from $\mathrm{Mcpt4}^{-/-}$mice

Human recombinant chymase; purified system/cell biological approaches Human skin MCs

Purified human chymase; chemotaxis assays Purified dog chymase In vivo data from $\mathrm{Mcpt4}^{-1-}$ mice

Purified mMCP4; in vivo findings from Mcpt4 ${ }^{-1-}$ mice Cell biological approaches; in vivo data from $\mathrm{Mcpt}^{-/-}$ mice

In vitro; in vivo data from $\mathrm{Mcpt}^{-1-}$ mice In vivo data from $\mathrm{Mcpt}^{-/-}$mice

Purified systems; cell biological approaches; in vivo data from Mcpt4 ${ }^{-1-}$ mice

Purified dog chymase; in vivo data from

$$
\mathrm{Mcpt}^{-1-} \text { mice }
$$

In vivo data from mice with mutated $\mathrm{Cpa3}$

Purified human CPA3; purified system

Purified human CPA3; purified system

Purified human CPA3; purified system

Purified human CPA3; purified system; cell biological
Degradation; blockade of VIP-induced SMC relaxation

Degradation

Degradation

ECM remodelling

Activation of pro-collagenase activity

Receptor activation

Degradation; blockade of eosinophil chemotaxis

Degradation; blockade of eosinophil chemotaxis

Degradation; removal of $\mathrm{N}$-terminal ends

Degradation; regulation of blood coagulation

Generation of anaphylatoxins (C3a, C5a)

\section{ECM remodelling}

Processing to active MMP2; ECM remodelling Processing to active MMP2; ECM remodelling Activation; pro-fibrotic activity; ECM remodelling

$$
\begin{gathered}
\text { Activation of collagenolytic activity; ECM } \\
\text { remodelling }
\end{gathered}
$$

Activation to IL-1 $\beta$; pro-inflammatory activity Degradation; blockade of pro-inflammatory activity Degradation; blockade of pro-inflammatory activity Activation; proposed pro-inflammatory activity in atopic disease

Degradation; blockade of pro-inflammatory activity

Degradation; blockade of pro-inflammatory activity: increased survival in sepsis

Activation; promotes CCR1 stimulation

Processing to active NAP-2/CXCL7

Degradation; abolished chemotactic activity Degradation

Degradation; blockade of pro-inflammatory activity

Degradation; regulation of blood coagulation

Degradation; Increased endothelial/epithelial permeability

Gained vasoconstrictor activity Skin blistering

$[87,88]$

$[91,92]$

[98-100]

[93-95]

$[96,97]$

$[89,90]$

$[23,85,107$ 108]

$[111,113]$

[110-112]

[123-125]

$[114,115]$

[114]

$[115,117]$

$[78,115,127]$

$[23,121,122]$

$[113,128]$

Activation to angiotensin I; degradation of angiotensin I; effects on vasoconstriction

Degradation; potential detrimental impact on asthma

$[120,135$

$[87,126]$

Degradation

Degradation

Degradation

Degradation

Degradation
$[9,137]$

$[133,134]$

$[133,134]$

[134]

$[135,136]$

VIP: vasoactive intestinal peptide; SMC: smooth muscle cell; CGRP: calcitonin gene-related peptide; PHM: peptide histidine-methionine; ECM: extracellular matrix; MMP: matrix metalloproteinase; PAR-2: proteinase-activated receptor-2; TGF: transforming growth factor; IL: interleukin; TNF: tumour necrosis factor; NAP-2: neutrophil activating peptide-2; CTAP-III: connective tissue-activating peptide-III; HMGB1: high mobility group box 1; CPA3: carboxypeptidase A3. 
by ex vivo findings in ferret tracheal rings [105]. Conversely, CGRP secreted from pulmonary neuroendocrine cells has recently been suggested to represent a pathogenic factor in asthmatic responses [106] and its degradation by tryptase could hence serve a protective function, in seeming contradiction to the proposed detrimental impact of tryptase in asthma. Furthermore, eotaxin and RANTES are strong eosinophil chemoattractants, and their degradation by tryptase could thus dampen eosinophil influx in the context of asthma, again in apparent discrepancy with a proposed harmful impact of tryptase in allergic lung inflammation.

Importantly, it should be noted that it has not been confirmed that any of the candidate tryptase substrates are indeed targets for tryptase in vivo under asthmatic conditions. Clearly, to understand the function of tryptase in asthma it will be important to identify its in vivo targets. This could be accomplished by, for example, using unbiased approaches such as comparing the lung tissue or BALF proteome of wild-type versus tryptase-null animals in models of asthma. Additional information could be obtained by comparing the transcriptome of lungs from tryptase-sufficient versus tryptase-deficient animals, or after tryptase inhibition, to potentially identify gene expression pathways that are targeted by tryptase.

\section{Chymase}

In contrast to tryptase, chymase is a monomeric protease and is thus not hampered by macromolecular constraints in its ability to cleave substrates. Accordingly, a large number of substrates for chymase have been identified, including fibronectin [23, 107, 108], pro-collagenase [109], pro-MMP9 [110-112], pro-MMP2 [111, 113], IL-6 [114, 115], IL-13 [114], IL-15 [115], IL-33 [78, 115], pro-IL-1ß [116], pro-IL-18 [115, 117], tumour necrosis factor [118], chemokines CCL6/9/15/23 [119], angiotensin I [120], thrombin $[23,121,122]$, latent transforming growth factor (TGF)- $\beta$ [123-125], VIP [87, 126], substance P [87], high mobility group box 1 [127], tight junction proteins [113, 128], Big-endothelin-1 [129], chemerin [130] and connective tissue-activating peptide-III [131] (table 2). Notably, in many cases chymase causes degradation of the respective substrates, i.e. abrogating their biological activities (e.g. fibronectin, thrombin, IL-33, IL-13, IL-6, VIP and substance P), whereas in other cases chymase causes activation of the respective compound by exerting limited proteolysis (table 2). Examples of the latter include pro-MMP2/9, pro-IL-1 $\beta$, pro-IL-18, latent TGF- $\beta$ and Big-endothelin-1 (table 2).

It is clear that the effects of chymase on several of its identified substrates could have the ability to influence the pathology of asthma. For example, cleavage (degradation) of IL-13, IL-33 and IL-6 could potentially contribute to a protective role of chymase in asthma, by attenuating the pro-inflammatory responses to these compounds and/or by affecting SMC contraction. Alternatively, activation of other cytokines such as IL-1 $\beta$ and IL-18 could have an opposite, i.e. pro-inflammatory, impact on airway inflammation. Overall, it is noteworthy that many of the identified chymase substrates are implicated in extracellular matrix (ECM) remodelling and it is thus possible that chymase can regulate such processes occurring in the context of asthma. For example, it is well established from both in vitro and in vivo studies that chymase has the ability to cleave and thereby activate pro-MMP2 and pro-MMP9 [110-113], which could serve to prevent excessive ECM deposition in the allergic airways. Activation of pro-collagenase by chymase could also contribute to this. Furthermore, it is well established from multiple approaches, including in vivo studies of lung tissue, that fibronectin is a major substrate for chymase [23, $85,107,108]$ and it is thus plausible that chymase could have a role in preventing excessive deposition of fibronectin under asthmatic conditions. Altogether, the combined effects of chymase on multiple ECM components could thus have a protective effect by dampening airway remodelling. Conversely, chymase has also been shown to cleave and thereby activate latent TGF- $\beta$, with the potential to promote ECM deposition in the allergic airways [123-125]. However, it remains to be established whether chymase has this ability in vivo; in fact, there are studies challenging this notion by showing that the levels of TGF- $\beta$ did not differ between wild-type and $M c p t 4^{-/-}$animals in a model of lung fibrosis [132].

\section{CPA3}

In comparison with tryptase and chymase, there is to date very limited insight into the substrate cleavage profile of CPA3. Previous studies in purified systems have shown that CPA3 can cleave neurotensin [133, 134], kinetensin [133, 134], neuromedin N [134] and angiotensin I [135, 136]. Moreover, there is evidence from in vivo approaches that endothelin-1 is a major substrate for CPA3 [9, 137]. Intriguingly, endothelin-1 has strong vasoconstrictor and pro-fibrotic properties; hence, it is possible that CPA3 could serve to regulate such processes in the context of asthma. However, this notion needs to be verified by dedicated approaches. The substrate cleavage profile of CPA3 has also been mapped by using a mass spectrometry-based approach [138]. 


\section{Effects of the MC proteases on airway cells}

When MCs degranulate, large quantities of the MC proteases are released. To some extent, the released MC proteases may diffuse to sites distant from the degranulating MCs and even enter the circulation. However, the MC proteases are secreted in large aggregates, complexed with serglycin proteoglycans, and these complexes tend to accumulate locally $[139,140]$. It is therefore likely that the impact of the MC proteases on asthmatic settings is largely due to the effects on cells residing in the local environment, e.g. SMCs, epithelial cells or fibroblasts. As elaborated in the following subsections, a number of studies have approached this topic (figure 2).

\section{SMCS}

The effect of chymase on airway SMCs has only been scarcely studied, but in one study it was shown that chymase degrades fibronectin and CD44 in the pericellular matrix of primary airway SMCs, and that chymase can block epidermal growth factor-induced SMC proliferation [141]. In line with these findings, chymase was shown to have potent pro-apoptotic effects on vascular and uterine SMCs [142-144]. This effect was dependent on fibronectin degradation, leading to decreased pro-survival Akt (protein kinase B) and NF- $\kappa B$ signalling $[142,143]$. Based on these findings, one plausible scenario could be that the protective effect of chymase in asthma can be attributed, at least partly, to its inhibitory action on airway SMCs.

Tryptase has been shown to stimulate SMC proliferation $[145,146]$. Mechanistically, there is indirect evidence that tryptase triggers SMC activation through PAR-2 activation $[147,148]$ and by triggering extracellular-regulated kinase (ERK) $1 / 2$ signalling [146]. However, other studies have suggested that
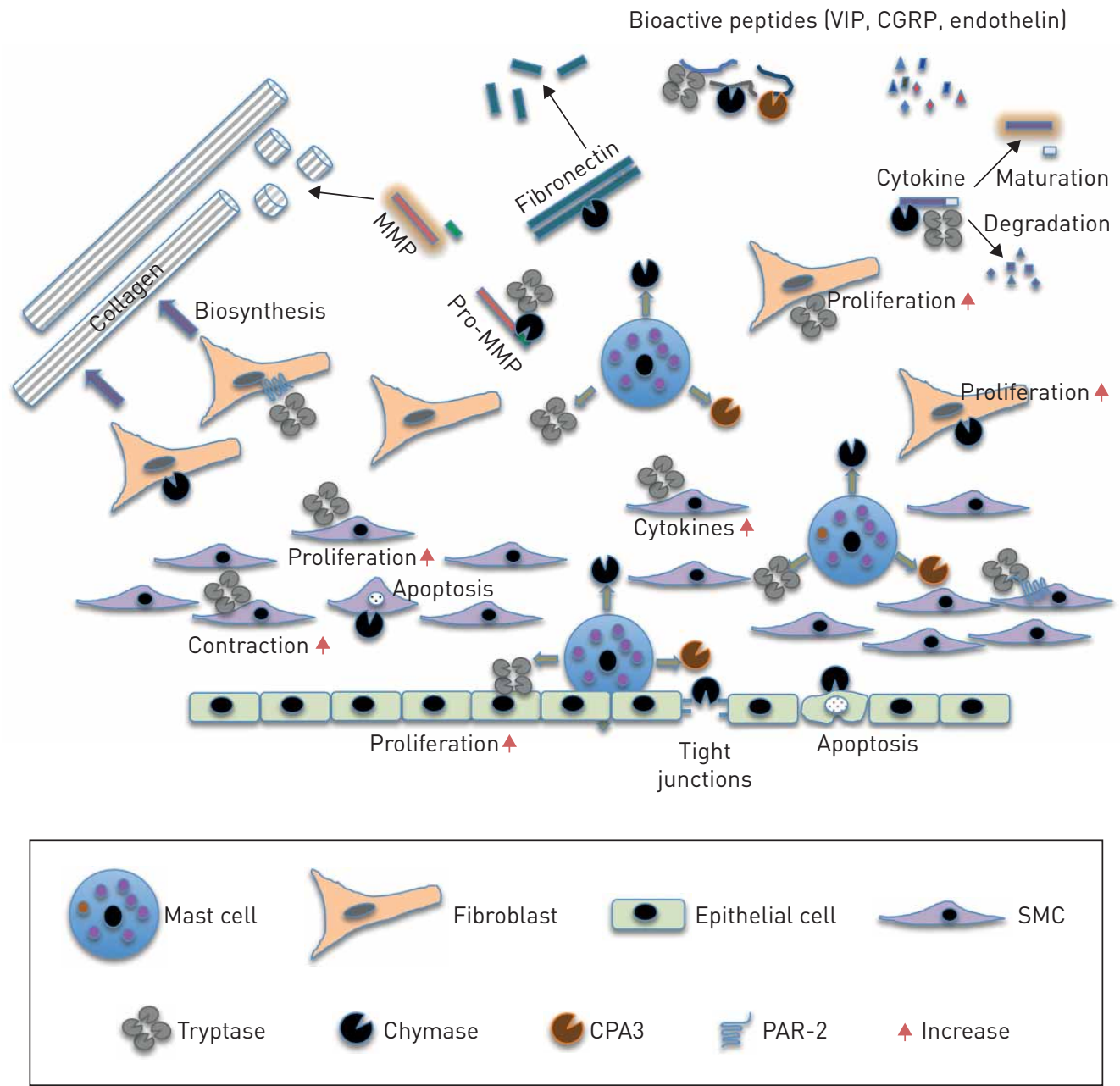

FIGURE 2 Effects of the mast cell proteases on lung cell populations. CPA3: carboxypeptidase A3; PAR-2: proteinase-activated receptor-2; SMC: smooth muscle cell; VIP: vasoactive intestinal peptide; CGRP: calcitonin gene-related peptide; MMP: matrix metalloproteinase. 
activation of airway SMCs by tryptase is independent of PAR-2 [149, 150]. Finally, several studies have shown that tryptase can induce or potentiate cytokine/chemokine release from airway SMCs [150-152], and it has also been shown that tryptase can induce and proteolytically activate latent TGF- $\beta[153,154]$.

\section{Fibroblasts}

Chymase has been shown to promote proliferation and collagen production in various types of fibroblasts, and there is evidence suggesting that chymase acts on fibroblasts by inducing the TGF- $\beta$ signalling pathway [155-157]. However, it was shown in one study that chymase decreases pro-collagen output from cardiac fibroblasts and, intriguingly, it was shown that chymase is taken up into fibroblasts by dynamin-dependent endocytosis [158].

Tryptase can also affect fibroblasts. In particular, numerous studies suggest that tryptase can stimulate proliferation and collagen synthesis in fibroblasts of various origin [159-168], and there is substantial evidence that tryptase acts on fibroblasts through PAR-2, ERK1/2 and peroxisome proliferator-activated receptor- $\gamma[160,165-168]$. It has also been shown that tryptase can induce chemokine synthesis in fibroblasts and promote fibroblast chemotaxis $[169,170]$. Clearly, these findings suggest that effects of tryptase on airway fibroblasts could contribute to the extensive connective tissue remodelling that occurs in asthma. However, the effect of tryptase on primary lung fibroblasts has only been scarcely studied [165]. Interestingly, tryptase can also promote myofibroblast differentiation [167, 171].

\section{Epithelial cells}

Chymase can affect epithelial cells, as exemplified by a recent study where it was shown that chymase causes dissociation of airway epithelial cells from the basement membrane of human bronchial rings [172]. Mechanistically, a number of studies have shown that chymase can cleave epithelial tight junction proteins such as claudin-3-5, occludin and zonula occludens-1 [113, 172-175], and chymase-mediated degradation of hemidesmosomes has also been reported [112]. Chymase can additionally stimulate mucin expression in epithelial cells [176], inhibit epithelial cell growth [177] and induce epithelial cell apoptosis [178].

The effect of tryptase on airway epithelial cells has been studied to some extent. In one study it was demonstrated that tryptase is a mitogen for an epithelial cell line of lung origin [179], and it has also been shown that tryptase stimulates prostaglandin $\mathrm{E}_{2}$ release from primary small airway epithelial cells [180] and IL-8 production in retinal epithelial cells [181]. In other studies it was shown that tryptase, in contrast to chymase (see earlier), does not cause increased permeability of airway or retinal epithelial cells [181, 182]. There are, however, conflicting studies indicating that tryptase can in fact affect the epithelial barrier function of epithelial cells $[183,184]$.

\section{Summary of effects of the MC proteases on airway cells}

Altogether, these findings indicate that the MC proteases can have profound effects on cell populations residing in the vicinity of MCs in lungs of asthmatic subjects and it is thus plausible that the impact of MCs on asthma pathology could be due to such effects. However, it should be emphasised that many of the studies on this issue were performed on either transformed cells or on cells of non-lung origin and it will therefore be important to assess whether the MC proteases impose corresponding effects on primary airway cells. Finally, it remains to be investigated whether CPA3 has an impact on any of these airway cell populations.

\section{MC proteases as drug targets}

Based on the notion that the MC proteases can have a pathogenic role in asthma, their inhibition may have therapeutic potential. To address this, previous efforts have mainly focused on tryptase inhibitors (table 3). In early reports, a beneficial effect of the tryptase inhibitor APC-366 was seen in a sheep model of allergic asthma induced by Ascaris suum sensitisation and challenge [185]. APC-366 has since been evaluated in allergic pigs and was proven to have beneficial effects [186]. These findings formed the basis for evaluating APC-366 in a small-scale clinical trial involving mild atopic asthmatic subjects. In this trial, APC-366 had a significant positive effect on the late-phase airway response against allergen [187]. However, it was later revealed that some APC-366-treated patients developed bronchospasm and the use of APC-366 for clinical purposes was abandoned. It should be noted that APC-366 is a very poor tryptase inhibitor, being extremely slow acting and with very limited selectivity for tryptase over other trypsin-like proteases (table 3) $[185,188]$, and it is therefore difficult to ascertain that its effects in vivo are due to targeting tryptase as opposed to other trypsin-like proteases. To account for this issue, more selective and more efficient tryptase inhibitors have been developed. These new-generation tryptase inhibitors are typically dibasic, i.e. they have dual active site-interacting domains $[189,190]$. One of them, AMG-126737, was assessed in allergen-induced airway responses in guinea pigs and sheep, and was proven to have efficacy [191]. Another potent, dibasic tryptase inhibitor is nafamostat [192]. It was shown to efficiently suppress both airway reactivity and inflammation in an ovalbumin-based mouse model of asthma [193, 
TABLE 3 Tryptase inhibitors used for treatment of allergic airway responses

\begin{tabular}{|c|c|c|c|c|c|}
\hline Inhibitor & $K_{\mathrm{i}} / \mathrm{IC}_{50}$ & $\begin{array}{l}\text { Selectivity over } \\
\text { trypsin fold }\end{array}$ & Setting & Outcome & Reference(s) \\
\hline \multirow[t]{3}{*}{ APC-366 } & $0.33-450 \mu \mathrm{M}$ & 0.5 & Antigen-challenged allergic sheep (A. suum) & $\begin{array}{l}\text { Inhibition of late-phase airway } \\
\text { reactivity; reduced inflammatory } \\
\text { response }\end{array}$ & [185] \\
\hline & & & Antigen-challenged allergic pigs (A. suum) & $\begin{array}{l}\text { Reduced airway responsiveness; } \\
\text { reduced histamine levels in urine }\end{array}$ & [186] \\
\hline & & & Clinical trial; mild atopic asthmatic subjects & $\begin{array}{l}\text { Positive effect on the late-phase } \\
\text { allergen response }\end{array}$ & [187] \\
\hline BABIM & $5 \mathrm{nM}$ & 18 & Antigen-challenged allergic sheep (A. suum) & $\begin{array}{l}\text { Inhibition of late-phase airway } \\
\text { reactivity }\end{array}$ & [185] \\
\hline Nafamostat & $0.016 \mathrm{nM}$ & 160 & $\begin{array}{l}\text { Antigen-challenged allergic mice (ovalbumin); } \\
\text { chronic model (Der p) }\end{array}$ & $\begin{array}{l}\text { Reduced airway reactivity; reduced } \\
\text { airway inflammation }\end{array}$ & [193-195] \\
\hline Gabexate & $3.4 \mathrm{nM}$ & 500 & $\begin{array}{l}\text { Antigen-challenged allergic mice (ovalbumin); } \\
\text { chronic model (Der p) }\end{array}$ & $\begin{array}{l}\text { Reduced airway reactivity; reduced } \\
\text { airway inflammation }\end{array}$ & {$[193,195]$} \\
\hline AMG-126737 & $90 \mathrm{nM}$ & 28 & $\begin{array}{c}\text { Antigen-challenged allergic sheep (A. suum); } \\
\text { antigen-challenged allergic guinea pigs } \\
\text { (ovalbumin) }\end{array}$ & Reduced airway reactivity & [191] \\
\hline BMS-262084 & $4 \mathrm{nM}$ & 18 & $\begin{array}{c}\text { Antigen-challenged allergic guinea pigs } \\
\text { (ovalbumin) }\end{array}$ & $\begin{array}{l}\text { Reduced airway reactivity and } \\
\text { inflammation }\end{array}$ & [196] \\
\hline MOL 6131 & $45 \mathrm{nM}$ & 24 & Antigen-challenged allergic mice (ovalbumin) & $\begin{array}{l}\text { Reduced airway inflammation; no } \\
\text { effect on inflammation }\end{array}$ & [197] \\
\hline
\end{tabular}

$K_{i}$ : inhibition constant; $I_{50:}$ median inhibitory concentration; $A$. suum: Ascaris suum.

194], as well as in a chronic model of asthma in mice [195]. Other tryptase inhibitors include BMS-262084, MOL 6131, gabexate, ulinastatin and RWJ-58643, all of which show beneficial effects in models of asthma [193, 195-198]. However, none of these new-generation tryptase inhibitors has been evaluated in humans.

More limited knowledge is available concerning the effects of chymase inhibitors in asthma. In one study it was shown that RWJ-355871 suppressed early- and late-phase airway reactivity in a sheep asthma model [199], this being in seeming discrepancy with the reported beneficial effects of chymase on asthma [33, 35, 77, 78]. However, RWJ-355871 is a dual cathepsin G/chymase inhibitor and its inhibitory effect on allergic airway responses could thereby be attributed to its effect on cathepsin G (or other chymotrypsin-like proteases) rather than chymase. More selective chymase inhibitors are now available [200], but have not been evaluated in models of asthma.

Based on novel findings implicating CPA3 in the pathogenesis of asthma [34, 38, 65, 68, 69], it would be of great interest to evaluate CPA3 inhibitors in asthma models. However, this has not yet been done.

\section{Conclusions and future directions}

As discussed here, there is now strong support for a contribution of the MC proteases to the manifestations of asthma, both from clinical investigations and experimental approaches in animal models. Based on this notion, it may be foreseen that in the near future the MC proteases could be further exploited for therapeutic and/or diagnostic purposes in asthma. However, several important issues remain to be resolved to fully understand the role of the MC proteases in asthmatic disease. One of these is to identify the proteolytic targets for the MC proteases in vivo, in asthmatic settings. Another important task is to further evaluate the impact of highly selective and efficient MC protease inhibitors in asthma.

Overall, it is intriguing to note that the MC proteases can constitute a double-edged sword in their impact on asthma (figure 3). For example, whereas tryptase has generally been shown to have detrimental functions in asthma, several lines of evidence point to a protective role for chymase. It is even more intriguing to note that each of the MC proteases can have potentially both detrimental and beneficial impacts on asthma. This is exemplified by tryptase, which promotes bronchial hyperreactivity in a variety of settings, but also has the ability to degrade pathogenic cytokines and chemokines. Similarly, chymase has activities that can potentially promote airway responses, but also numerous activities that can serve to dampen manifestations of asthma. Clearly, it will be challenging to reconcile these observations and to 


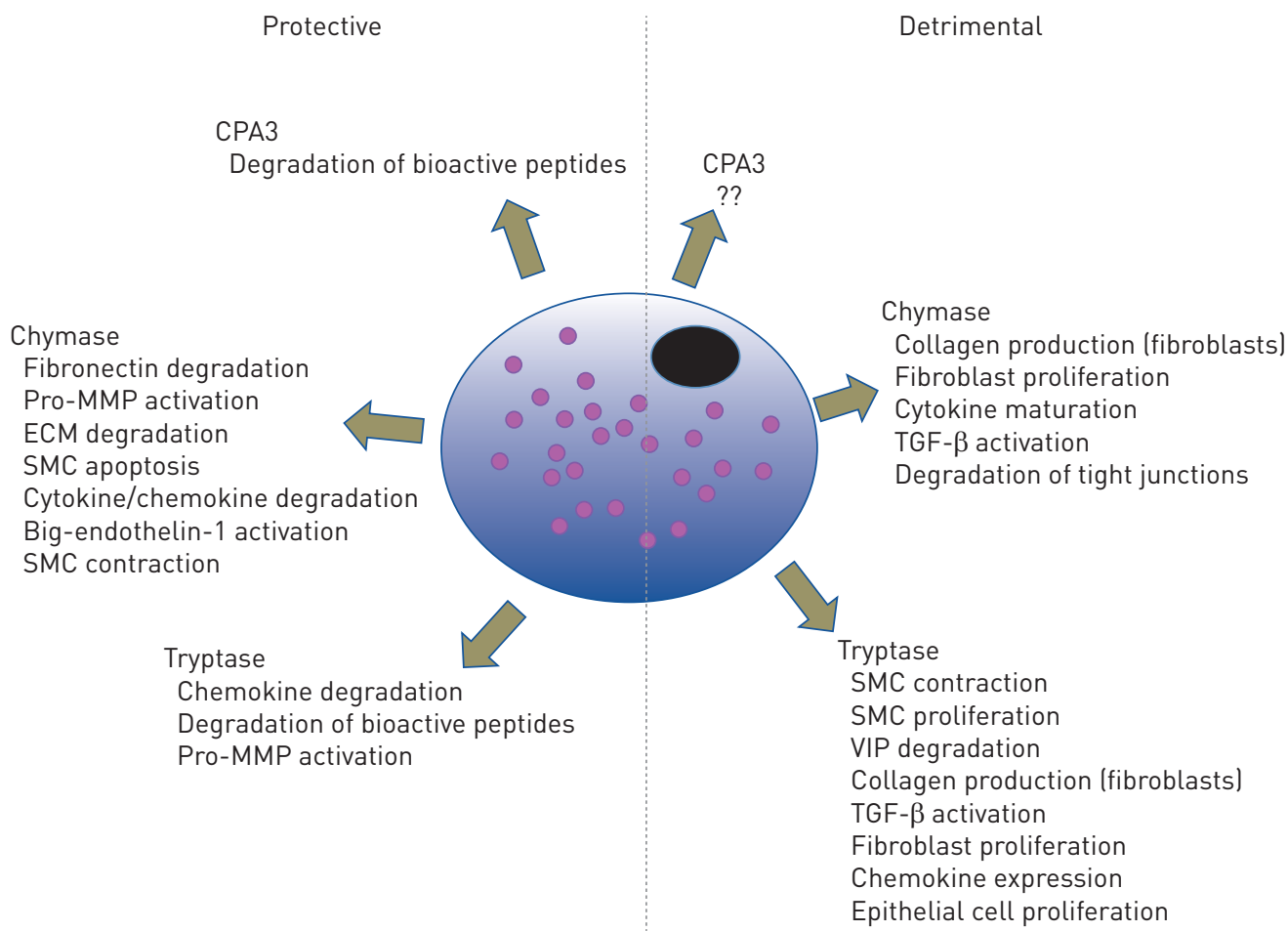

FIGURE 3 Pro- and anti-asthma effects of the mast cell proteases. CPA3: carboxypeptidase A3; MMP: matrix metalloproteinase; ECM: extracellular matrix; SMC: smooth muscle cell; TGF: transforming growth factor; VIP: vasoactive intestinal peptide.

outline at the molecular level how the MC proteases influence the pathology in various settings and phases of asthma.

Conflict of interest: G. Pejler has nothing to disclose.

Support statement: This work was supported by Barncancerfonden, Cancerfonden, Hjärt-Lungfonden, Knut och Alice Wallenbergs Stiftelse and Vetenskapsrådet. Funding information for this article has been deposited with the Crossref Funder Registry.

\section{References}

1 Gurish MF, Austen KF. Developmental origin and functional specialization of mast cell subsets. Immunity 2012; 37: 25-33.

2 Wernersson S, Pejler G. Mast cell granules: armed for battle. Nat Rev Immunol 2014; 14: 478-494.

3 Pejler G, Rönnberg E, Waern I, et al. Mast cell proteases: multifaceted regulators of inflammatory disease. Blood 2010; 115: 4981-4990.

4 Pejler G, Knight SD, Henningsson F, et al. Novel insights into the biological function of mast cell carboxypeptidase A. Trends Immunol 2009; 30: 401-408.

$5 \quad$ Pejler G, Ảbrink M, Ringvall M, et al. Mast cell proteases. Adv Immunol 2007; 95: 167-255.

6 Galli SJ, Nakae S, Tsai M. Mast cells in the development of adaptive immune responses. Nat Immunol 2005; 6: $135-142$.

7 Dawicki W, Marshall JS. New and emerging roles for mast cells in host defence. Curr Opin Immunol 2007; 19 31-38.

8 Johnzon CF, Rönnberg E, Pejler G. The role of mast cells in bacterial infection. Am J Pathol 2016; 186: 4-14.

9 Metz M, Piliponsky AM, Chen CC, et al. Mast cells can enhance resistance to snake and honeybee venoms. Science 2006; 313: 526-530.

10 Voehringer D. Protective and pathological roles of mast cells and basophils. Nat Rev Immunol 2013; 13: 362-375. Bradding P, Arthur G. Mast cells in asthma - state of the art. Clin Exp Allergy 2016; 46: 194-263.

Galli SJ, Tsai M. IgE and mast cells in allergic disease. Nat Med 2012; 18: 693-704.

Erjefalt JS. Mast cells in human airways: the culprit? Eur Respir Rev 2014; 23: 299-307.

Andersson C, Tufvesson E, Diamant Z, et al. Revisiting the role of the mast cell in asthma. Curr Opin Pulm Med 2016; 22: 10-17.

15 Brightling CE, Bradding P, Symon FA, et al. Mast-cell infiltration of airway smooth muscle in asthma. $N$ Engl $J$ Med 2002; 346: 1699-1705.

16 Amin K, Janson C, Boman G, et al. The extracellular deposition of mast cell products is increased in hypertrophic airways smooth muscles in allergic asthma but not in nonallergic asthma. Allergy 2005; 60: $1241-1247$. 
Andersson CK, Bergqvist A, Mori M, et al. Mast cell-associated alveolar inflammation in patients with atopic uncontrolled asthma. J Allergy Clin Immunol 2011; 127: 905-912.

Djukanovic R, Wilson SJ, Kraft M, et al. Effects of treatment with anti-immunoglobulin E antibody omalizumab on airway inflammation in allergic asthma. Am J Respir Crit Care Med 2004; 170: 583-593.

Yu M, Tsai M, Tam SY, et al. Mast cells can promote the development of multiple features of chronic asthma in mice. J Clin Invest 2006; 116: 1633-1641.

Williams CM, Galli SJ. Mast cells can amplify airway reactivity and features of chronic inflammation in an asthma model in mice. J Exp Med 2000; 192: 455-462.

Sawaguchi M, Tanaka S, Nakatani Y, et al. Role of mast cells and basophils in IgE responses and in allergic airway hyperresponsiveness. J Immunol 2012; 188: 1809-1818.

Hellman L, Thorpe M. Granule proteases of hematopoietic cells, a family of versatile inflammatory mediators an update on their cleavage specificity, in vivo substrates, and evolution. Biol Chem 2014; 395: 15-49.

Tchougounova E, Pejler G, Åbrink M. The chymase, mouse mast cell protease 4, constitutes the major chymotrypsin-like activity in peritoneum and ear tissue. A role for mouse mast cell protease 4 in thrombin regulation and fibronectin turnover. J Exp Med 2003; 198: 423-431.

Andersson MK, Enoksson M, Gallwitz M, et al. The extended substrate specificity of the human mast cell chymase reveals a serine protease with well-defined substrate recognition profile. Int Immunol 2009; 21: 95-104.

Andersson MK, Karlson U, Hellman L. The extended cleavage specificity of the rodent beta-chymases rMCP-1 and mMCP-4 reveal major functional similarities to the human mast cell chymase. Mol Immunol 2008; 45: 766-775.

Marquardt U, Zettl F, Huber R, et al. The crystal structure of human alpha1-tryptase reveals a blocked substrate-binding region. J Mol Biol 2002; 321: 491-502.

Huang C, Li L, Krilis SA, et al. Human tryptases alpha and beta/II are functionally distinct due, in part, to a single amino acid difference in one of the surface loops that forms the substrate-binding cleft. J Biol Chem 1999; 274: 19670-19676.

Soto D, Malmsten C, Blount JL, et al. Genetic deficiency of human mast cell alpha-tryptase. Clin Exp Allergy 2002; 32: 1000-1006.

Caughey GH. Tryptase genetics and anaphylaxis. J Allergy Clin Immunol 2006; 117: 1411-1414.

Caughey GH, Raymond WW, Blount JL, et al. Characterization of human gamma-tryptases, novel members of the chromosome 16p mast cell tryptase and prostasin gene families. J Immunol 2000; 164: 6566-6575.

Irani AA, Schechter NM, Craig SS, et al. Two types of human mast cells that have distinct neutral protease compositions. Proc Natl Acad Sci USA 1986; 83: 4464-4468.

Sverrild A, Bergqvist A, Baines KJ, et al. Airway responsiveness to mannitol in asthma is associated with chymase-positive mast cells and eosinophilic airway inflammation. Clin Exp Allergy 2016; 46: 288-297.

Zanini A, Chetta A, Saetta M, et al. Chymase-positive mast cells play a role in the vascular component of airway remodeling in asthma. J Allergy Clin Immunol 2007; 120: 329-333.

Balzar S, Fajt ML, Comhair SA, et al. Mast cell phenotype, location, and activation in severe asthma. Data from the Severe Asthma Research Program. Am J Respir Crit Care Med 2011; 183: 299-309.

Balzar S, Chu HW, Strand M, et al. Relationship of small airway chymase-positive mast cells and lung function in severe asthma. Am J Respir Crit Care Med 2005; 171: 431-439.

Van der Velden J, Barker D, Barcham G, et al. Increased mast cell density and airway responses to allergic and non-allergic stimuli in a sheep model of chronic asthma. PLoS One 2012; 7: e37161.

Schmit D, Le DD, Heck S, et al. Allergic airway inflammation induces migration of mast cell populations into the mouse airway. Cell Tissue Res 2017; 369: 331-340.

Dougherty RH, Sidhu SS, Raman K, et al. Accumulation of intraepithelial mast cells with a unique protease phenotype in $\mathrm{T}_{\mathrm{H}}$ 2-high asthma. J Allergy Clin Immunol 2010; 125: 1046-1053.

Lai Y, Altemeier WA, Vandree J, et al. Increased density of intraepithelial mast cells in patients with exercise-induced bronchoconstriction regulated through epithelially derived thymic stromal lymphopoietin and IL-33. J Allergy Clin Immunol 2014; 133: 1448-1455.

Hallstrand TS, Wurfel MM, Lai Y, et al. Transglutaminase 2, a novel regulator of eicosanoid production in asthma revealed by genome-wide expression profiling of distinct asthma phenotypes. PLoS One 2010; 5: e8583.

Gao S, Fan J, Wang Z. Diagnostic value of serum baseline tryptase levels in childhood asthma and its correlation with disease severity. Int Arch Allergy Immunol 2016; 171: 194-202.

Taira M, Tamaoki J, Kondo M, et al. Serum B12 tryptase level as a marker of allergic airway inflammation in asthma. J Asthma 2002; 39: 315-322.

Scarpelli MP, Keller S, Tran L, et al. Postmortem serum levels of IgE and mast cell tryptase in fatal asthma. Forensic Sci Int 2016; 269: 113-118.

Bochenek G, Nagraba K, Nizankowska E, et al. A controlled study of 9alpha,11beta- $\mathrm{PGF}_{2}$ (a prostaglandin $\mathrm{D}_{2}$ metabolite) in plasma and urine of patients with bronchial asthma and healthy controls after aspirin challenge. J Allergy Clin Immunol 2003; 111: 743-749.

Rao R, Frederick JM, Enander I, et al. Airway function correlates with circulating eosinophil, but not mast cell, markers of inflammation in childhood asthma. Clin Exp Allergy 1996; 26: 789-793.

Fenger RV, Linneberg A, Vidal C, et al. Determinants of serum tryptase in a general population: the relationship of serum tryptase to obesity and asthma. Int Arch Allergy Immunol 2012; 157: 151-158.

Bochenek G, Nizankowska E, Gielicz A, et al. Plasma 9alpha,11beta-PGF 2 , a $\mathrm{PGD}_{2}$ metabolite, as a sensitive marker of mast cell activation by allergen in bronchial asthma. Thorax 2004; 59: 459-464.

Medrala W, Malolepszy J, Wolanczyk-Medrala A, et al. Is mast cell activation during asthmatic reaction reflected in the circulation? J Investig Allergol Clin Immunol 1995; 5: 343-346.

Salkie ML, Mitchell I, Revers CW, et al. Postmortem serum levels of tryptase and total and specific IgE in fatal asthma. Allergy Asthma Proc 1998; 19: 131-133.

Sverrild A, van der Sluis S, Kyvik KO, et al. Genetic factors account for most of the variation in serum tryptase a twin study. Ann Allergy Asthma Immunol 2013; 111: 286-289.

Hallstrand TS, Moody MW, Wurfel MM, et al. Inflammatory basis of exercise-induced bronchoconstriction. Am J Respir Crit Care Med 2005; 172: 679-686. 
Bettiol J, Radermecker M, Sele J, et al. Airway mast-cell activation in asthmatics is associated with selective sputum eosinophilia. Allergy 1999; 54: 1188-1193.

von Ungern-Sternberg BS, Sly PD, Loh RK, et al. Value of eosinophil cationic protein and tryptase levels in bronchoalveolar lavage fluid for predicting lung function impairment in anaesthetised, asthmatic children. Anaesthesia 2006; 61: 1149-1154.

Alvarez MJ, Olaguibel JM, Garcia BE, et al. Airway inflammation in asthma and perennial allergic rhinitis. Relationship with nonspecific bronchial responsiveness and maximal airway narrowing. Allergy 2000; 55: 355-362.

Louis R, Lau LC, Bron AO, et al. The relationship between airways inflammation and asthma severity. Am $J$ Respir Crit Care Med 2000; 161: 9-16.

Ferguson AC, Whitelaw M, Brown H. Correlation of bronchial eosinophil and mast cell activation with bronchia hyperresponsiveness in children with asthma. J Allergy Clin Immunol 1992; 90: 609-613.

Jarjour NN, Calhoun WI, Schwartz LB, et al. Elevated bronchoalveolar lavage fluid histamine levels in allergic asthmatics are associated with increased airway obstruction. Am Rev Respir Dis 1991; 144: 83-87.

Broide DH, Eisman S, Ramsdell JW, et al. Airway levels of mast cell-derived mediators in exercise-induced asthma. Am Rev Respir Dis 1990; 141: 563-568.

Wenzel SE, Fowler AA 3rd, Schwartz LB. Activation of pulmonary mast cells by bronchoalveolar allergen challenge. In vivo release of histamine and tryptase in atopic subjects with and without asthma. Am Rev Respir Dis 1988; 137: 1002-1008.

Ennis M, Turner G, Schock BC, et al. Inflammatory mediators in bronchoalveolar lavage samples from children with and without asthma. Clin Exp Allergy 1999; 29: 362-366.

Fahy JV, Liu J, Wong H, et al. Cellular and biochemical analysis of induced sputum from asthmatic and from healthy subjects. Am Rev Respir Dis 1993; 147: 1126-1131.

Krug N, Hohlfeld JM, Kirsten AM, et al. Allergen-induced asthmatic responses modified by a GATA3-specific DNAzyme. N Engl J Med 2015; 372: 1987-1995.

Motakis E, Guhl S, Ishizu Y, et al. Redefinition of the human mast cell transcriptome by deep-CAGE sequencing Blood 2014; 123: e58-e67.

Dwyer DF, Barrett NA, Austen KF, et al. Expression profiling of constitutive mast cells reveals a unique identity within the immune system. Nat Immunol 2016; 17: 878-887.

, Simpson $L$, Wood LG, et al. Sputum gene expression signature of 6 biomarkers discriminates asthma inflammatory phenotypes. J Allergy Clin Immunol 2014; 133: 997-1007.

Berthon BS, Gibson PG, Wood LG, et al. A sputum gene expression signature predicts oral corticosteroid response in asthma. Eur Respir J 2017; 49: 1700180.

Fricker M, Gibson PG, Powell H, et al. A sputum 6-gene signature predicts future exacerbations of poorly controlled asthma. J Allergy Clin Immunol 2019; 144: 51-60.

Peters MC, Mekonnen ZK, Yuan S, et al. Measures of gene expression in sputum cells can identify $\mathrm{T}_{\mathrm{H}} 2$-high and $\mathrm{T}_{\mathrm{H}}$ 2-low subtypes of asthma. J Allergy Clin Immunol 2014; 133: 388-394.

Wang G, Baines KJ, Fu JJ, et al. Sputum mast cell subtypes relate to eosinophilia and corticosteroid response in asthma. Eur Respir J 2016; 47: 1123-1133.

Sharma S, Rajan UM, Kumar A, et al. A novel $(\mathrm{TG})_{n}(\mathrm{GA})_{m}$ repeat polymorphism 254 bp downstream of the mast cell chymase (CMA1) gene is associated with atopic asthma and total serum IgE levels. J Hum Genet 2005; 50: 276-282.

Hossny EM, Amr NH, Elsayed SB, et al. Association of polymorphisms in the mast cell chymase gene promoter region $(-1903 \mathrm{G} / \mathrm{A})$ and $(\mathrm{TG})_{n}(\mathrm{GA})_{m}$ repeat downstream of the gene with bronchial asthma in children. J Investig Allergol Clin Immunol 2008; 18: 376-381.

Hersberger M, Thun GA, Imboden M, et al. Association of STR polymorphisms in CMA1 and IL-4 with asthma and atopy: the SAPALDIA cohort. Hum Immunol 2010; 71: 1154-1160.

Iwanaga T, McEuen A, Walls AF, et al. Polymorphism of the mast cell chymase gene (CMA1) promoter region: lack of association with asthma but association with serum total immunoglobulin $\mathrm{E}$ levels in adult atopic dermatitis. Clin Exp Allergy 2004; 34: 1037-1042.

Trivedi NN, Tamraz B, Chu C, et al. Human subjects are protected from mast cell tryptase deficiency despite frequent inheritance of loss-of-function mutations. J Allergy Clin Immunol 2009; 124: 1099-1105.

Abdelmotelb AM, Rose-Zerilli MJ, Barton SJ, et al. Alpha-tryptase gene variation is associated with levels of circulating IgE and lung function in asthma. Clin Exp Allergy 2014; 44: 822-830.

Lyons JJ, Yu X, Hughes JD, et al. Elevated basal serum tryptase identifies a multisystem disorder associated with increased TPSAB1 copy number. Nat Genet 2016; 48: 1564-1569.

Waern I, Jonasson S, Hjoberg J, et al. Mouse mast cell protease 4 is the major chymase in murine airways and has a protective role in allergic airway inflammation. J Immunol 2009; 183: 6369-6376.

Waern I, Lundequist A, Pejler G, et al. Mast cell chymase modulates IL-33 levels and controls allergic sensitization in dust-mite induced airway inflammation. Mucosal Immunol 2013; 6: 911-920.

Sugimoto K, Kudo M, Sundaram A, et al. The alphavbeta6 integrin modulates airway hyperresponsiveness in mice by regulating intraepithelial mast cells. J Clin Invest 2012; 122: 748-758.

Cui Y, Dahlin JS, Feinstein R, et al. Mouse mast cell protease-6 and MHC are involved in the development of experimental asthma. J Immunol 2014; 193: 4783-4789.

Molinari JF, Scuri M, Moore WR, et al. Inhaled tryptase causes bronchoconstriction in sheep via histamine release. Am J Respir Crit Care Med 1996; 154: 649-653.

Barrios VE, Middleton SC, Kashem MA, et al. Tryptase mediates hyperresponsiveness in isolated guinea pig bronchi. Life Sci 1998; 63: 2295-2303.

Berger P, Compton SJ, Molimard M, et al. Mast cell tryptase as a mediator of hyperresponsiveness in human isolated bronchi. Clin Exp Allergy 1999; 29: 804-812.

Wong GW, Foster PS, Yasuda S, et al. Biochemical and functional characterization of human transmembrane tryptase (TMT)/tryptase gamma. TMT is an exocytosed mast cell protease that induces airway hyperresponsiveness in vivo via an interleukin-13/interleukin-4 receptor alpha/signal transducer and activator of transcription (STAT) 6-dependent pathway. J Biol Chem 2002; 277: 41906-41915. 

hyperresponsiveness in experimental asthma. J Clin Invest 2017; 127: 365-374.

86 Pereira PJ, Bergner A, Macedo-Ribeiro S, et al. Human beta-tryptase is a ring-like tetramer with active sites facing a central pore. Nature 1998; 392: 306-311.

87 Caughey GH, Leidig F, Viro NF, et al. Substance P and vasoactive intestinal peptide degradation by mast cell tryptase and chymase. J Pharmacol Exp Ther 1988; 244: 133-137.

88 Tam EK, Caughey GH. Degradation of airway neuropeptides by human lung tryptase. Am J Respir Cell Mol Biol 1990; 3: 27-32.

89 Schwartz LB, Bradford TR, Littman BH, et al. The fibrinogenolytic activity of purified tryptase from human lung mast cells. J Immunol 1985; 135: 2762-2767.

90 Prieto-Garcia A, Zheng D, Adachi R, et al. Mast cell restricted mouse and human tryptase-heparin complexes hinder thrombin-induced coagulation of plasma and the generation of fibrin by proteolytically destroying fibrinogen. J Biol Chem 2012; 287: 7834-7844.

91 Fajardo I, Pejler G. Human mast cell beta-tryptase is a gelatinase. J Immunol 2003; 171: 1493-1499.

92 Raymond WW, Sommerhoff CP, Caughey GH. Mastin is a gelatinolytic mast cell peptidase resembling a mini-proteasome. Arch Biochem Biophys 2005; 435: 311-322.

93 Corvera CU, Dery O, McConalogue $\mathrm{K}$, et al. Mast cell tryptase regulates rat colonic myocytes through proteinase-activated receptor 2. J Clin Invest 1997; 100: 1383-1393.

94 Mirza H, Schmidt VA, Derian CK, et al. Mitogenic responses mediated through the proteinase-activated receptor-2 are induced by expressed forms of mast cell alpha- or beta-tryptases. Blood 1997; 90: 3914-3922.

95 Molino M, Barnathan ES, Numerof R, et al. Interactions of mast cell tryptase with thrombin receptors and PAR-2. J Biol Chem 1997; 272: 4043-4049.

96 Pang L, Nie M, Corbett L, et al. Mast cell beta-tryptase selectively cleaves eotaxin and RANTES and abrogates their eosinophil chemotactic activities. I Immunol 2006; 176: 3788-3795.

97 Saunders R, Sutcliffe A, Woodman L, et al. The airway smooth muscle CCR3/CCL11 axis is inhibited by mast cells. Allergy 2008; 63: 1148-1155.

98 Naveed SU, Clements D, Jackson DJ, et al. Matrix metalloproteinase-1 activation contributes to airway smooth muscle growth and asthma severity. Am J Respir Crit Care Med 2017; 195: 1000-1009.

99 Gruber BL, Marchese MJ, Suzuki K, et al. Synovial procollagenase activation by human mast cell tryptase dependence upon matrix metalloproteinase 3 activation. J Clin Invest 1989; 84: 1657-1662.

100 Magarinos NJ, Bryant KJ, Fosang AJ, et al. Mast cell-restricted, tetramer-forming tryptases induce aggrecanolysis in articular cartilage by activating matrix metalloproteinase-3 and -13 zymogens. J Immunol 2013; 191: 1404-1412.

101 Fukuoka Y, Xia HZ, Sanchez-Munoz LB, et al. Generation of anaphylatoxins by human beta-tryptase from C3, C4, and C5. J Immunol 2008; 180: 6307-6316.

102 Melo FR, Vita F, Berent-Maoz B, et al. Proteolytic histone modification by mast cell tryptase, a serglycin proteoglycan-dependent secretory granule protease. J Biol Chem 2014; 289: 7682-7690.

103 Misaka S, Sato H, Aoki Y, et al. Novel vasoactive intestinal peptide derivatives with improved stability protect rat alveolar L2 cells from cigarette smoke-induced cytotoxicity and apoptosis. Peptides 2011; 32: 401-407.

104 Athari SS, Pourpak Z, Folkerts G, et al. Conjugated alpha-alumina nanoparticle with vasoactive intestinal peptide as a nano-drug in treatment of allergic asthma in mice. Eur J Pharmacol 2016; 791: 811-820.

105 Franconi GM, Graf PD, Lazarus SC, et al. Mast cell tryptase and chymase reverse airway smooth muscle relaxation induced by vasoactive intestinal peptide in the ferret. J Pharmacol Exp Ther 1989; 248: 947-951.

106 Sui P, Wiesner DL, Xu J, et al. Pulmonary neuroendocrine cells amplify allergic asthma responses. Science 2018; 360: eaan8546.

107 Vartio T, Seppa H, Vaheri A. Susceptibility of soluble and matrix fibronectins to degradation by tissue proteinases, mast cell chymase and cathepsin G. J Biol Chem 1981; 256: 471-477.

108 Beghdadi W, Madjene LC, Claver J, et al. Mast cell chymase protects against renal fibrosis in murine unilateral ureteral obstruction. Kidney Int 2013; 84: 317-326.

109 Saarinen J, Kalkkinen N, Welgus HG, et al. Activation of human interstitial procollagenase through direct cleavage of the Leu ${ }^{83}-\mathrm{Thr}^{84}$ bond by mast cell chymase. J Biol Chem 1994; 269: 18134-18140.

110 Fang KC, Raymond WW, Lazarus SC, et al. Dog mastocytoma cells secrete a 92-kD gelatinase activated extracellularly by mast cell chymase. J Clin Invest 1996; 97: 1589-1596.

111 Tchougounova E, Lundequist A, Fajardo I, et al. A key role for mast cell chymase in the activation of pro-matrix metalloprotease-9 and pro-matrix metalloprotease-2. J Biol Chem 2005; 280: 9291-9296.

112 Lin L, Bankaitis E, Heimbach L, et al. Dual targets for mouse mast cell protease-4 in mediating tissue damage in experimental bullous pemphigoid. J Biol Chem 2011; 286: 37358-37367.

113 Groschwitz KR, Wu D, Osterfeld H, et al. Chymase-mediated intestinal epithelial permeability is regulated by a protease-activating receptor/matrix metalloproteinase-2-dependent mechanism. Am J Physiol Gastrointest Liver Physiol 2013; 304: G479-G489.

114 Zhao W, Oskeritzian CA, Pozez AL, et al. Cytokine production by skin-derived mast cells: endogenous proteases are responsible for degradation of cytokines. J Immunol 2005; 175: 2635-2642.

115 Fu Z, Thorpe M, Alemayehu R, et al. Highly selective cleavage of cytokines and chemokines by the human mast cell chymase and neutrophil cathepsin G. J Immunol 2017; 198: 1474-1483.

116 Mizutani H, Schechter N, Lazarus G, et al. Rapid and specific conversion of precursor interleukin 1 beta (IL-1 beta) to an active IL-1 species by human mast cell chymase. J Exp Med 1991; 174: 821-825.

117 Omoto Y, Tokime K, Yamanaka K, et al. Human mast cell chymase cleaves pro-IL-18 and generates a novel and biologically active IL-18 fragment. J Immunol 2006; 177: 8315-8319.

118 Piliponsky AM, Chen CC, Rios EJ, et al. The chymase mouse mast cell protease 4 degrades TNF, limits inflammation, and promotes survival in a model of sepsis. Am J Pathol 2012; 181: 875-886.

119 Berahovich RD, Miao Z, Wang Y, et al. Proteolytic activation of alternative CCR1 ligands in inflammation. J Immunol 2005; 174: 7341-7351.

120 Urata H, Kinoshita A, Misono KS, et al. Identification of a highly specific chymase as the major angiotensin II-forming enzyme in the human heart. J Biol Chem 1990; 265: 22348-22357. 
121 Pejler G, Karlström A. Thrombin is inactivated by mast cell secretory granule chymase. J Biol Chem 1993; 268: $11817-11822$

122 Suender CA, Leist M, Abrink M, et al. Mast cells are critical for the limitation of thrombin-induced skin inflammation. Exp Dermatol 2018; 27: 50-57.

123 Taipale J, Lohi J, Saarinen J, et al. Human mast cell chymase and leukocyte elastase release latent transforming growth factor-beta 1 from the extracellular matrix of cultured human epithelial and endothelial cells. J Biol Chem 1995; 270: 4689-4696.

124 Wang Y, Shiota N, Leskinen MJ, et al. Mast cell chymase inhibits smooth muscle cell growth and collagen expression in vitro: transforming growth factor-betal-dependent and -independent effects. Arterioscler Thromb Vasc Biol 2001; 21: 1928-1933.

125 Cho SH, Lee SH, Kato A, et al. Cross-talk between human mast cells and bronchial epithelial cells in plasminogen activator inhibitor-1 production via transforming growth factor-betal. Am J Respir Cell Mol Biol 2015; 52: 88-95.

126 Akahoshi M, Song CH, Piliponsky AM, et al. Mast cell chymase reduces the toxicity of Gila monster venom, scorpion venom, and vasoactive intestinal polypeptide in mice. J Clin Invest 2011; 121: 4180-4191.

127 Roy A, Ganesh G, Sippola H, et al. Mast cell chymase degrades the alarmins heat shock protein 70, biglycan, HMGB1, and interleukin-33 (IL-33) and limits danger-induced inflammation. J Biol Chem 2014; 289: 237-250.

128 Bankova LG, Lezcano C, Pejler G, et al. Mouse mast cell proteases 4 and 5 mediate epidermal injury through disruption of tight junctions. J Immunol 2014; 192: 2812-2820.

129 Houde M, Jamain MD, Labonte J, et al. Pivotal role of mouse mast cell protease 4 in the conversion and pressor properties of Big-endothelin-1. J Pharmacol Exp Ther 2013; 346: 31-37.

130 Guillabert A, Wittamer V, Bondue B, et al. Role of neutrophil proteinase 3 and mast cell chymase in chemerin proteolytic regulation. J Leukoc Biol 2008; 84: 1530-1538.

131 Schiemann F, Grimm TA, Hoch J, et al. Mast cells and neutrophils proteolytically activate chemokine precursor CTAP-III and are subject to counterregulation by PF-4 through inhibition of chymase and cathepsin G. Blood 2006; 107: 2234-2242.

132 Reber LL, Daubeuf F, Pejler G, et al. Mast cells contribute to bleomycin-induced lung inflammation and injury in mice through a chymase/mast cell protease 4-dependent mechanism. J Immunol 2014; 192: 1847-1854.

133 Goldstein SM, Leong J, Bunnett NW. Human mast cell proteases hydrolyze neurotensin, kinetensin and Leu5-enkephalin. Peptides 1991; 12: 995-1000.

134 Bunnett NW, Goldstein SM, Nakazato P. Isolation of a neuropeptide-degrading carboxypeptidase from the human stomach. Gastroenterology 1992; 102: 76-87.

135 Lundequist A, Tchougounova E, Abrink M, et al. Cooperation between mast cell carboxypeptidase A and the chymase mouse mast cell protease 4 in the formation and degradation of angiotensin II. J Biol Chem 2004; 279: 32339-32344.

136 Scandiuzzi L, Beghdadi W, Daugas E, et al. Mouse mast cell protease-4 deteriorates renal function by contributing to inflammation and fibrosis in immune complex-mediated glomerulonephritis. J Immunol 2010; 185: 624-633.

137 Schneider LA, Schlenner SM, Feyerabend TB, et al. Molecular mechanism of mast cell mediated innate defense against endothelin and snake venom sarafotoxin. J Exp Med 2007; 204: 2629-2639.

138 Tanco S, Lorenzo J, Garcia-Pardo J, et al. Proteome-derived peptide libraries to study the substrate specificity profiles of carboxypeptidases. Mol Cell Proteomics 2013; 12: 2096-2110.

139 Ghildyal N, Friend DS, Stevens RL, et al. Fate of two mast cell tryptases in V3 mastocytosis and normal BALB/c mice undergoing passive systemic anaphylaxis: prolonged retention of exocytosed mMCP-6 in connective tissues, and rapid accumulation of enzymatically active mMCP-7 in the blood. J Exp Med 1996; 184: 1061-1073.

140 Schwartz LB, Riedel C, Caulfield JP, et al. Cell association of complexes of chymase, heparin proteoglycan, and protein after degranulation by rat mast cells. J Immunol 1981; 126: 2071-2078.

141 Lazaar AL, Plotnick MI, Kucich U, et al. Mast cell chymase modifies cell-matrix interactions and inhibits mitogen-induced proliferation of human airway smooth muscle cells. J Immunol 2002; 169: 1014-1020.

142 Leskinen MJ, Lindstedt KA, Wang Y, et al. Mast cell chymase induces smooth muscle cell apoptosis by a mechanism involving fibronectin degradation and disruption of focal adhesions. Arterioscler Thromb Vasc Biol 2003; 23: 238-243.

143 Leskinen MJ, Heikkila HM, Speer MY, et al. Mast cell chymase induces smooth muscle cell apoptosis by disrupting NF-kappaB-mediated survival signaling. Exp Cell Res 2006; 312: 1289-1298.

144 Meyer N, Woidacki K, Knofler M, et al. Chymase-producing cells of the innate immune system are required for decidual vascular remodeling and fetal growth. Sci Rep 2017; 7: 45106.

145 Brown JK, Tyler CL, Jones CA, et al. Tryptase, the dominant secretory granular protein in human mast cells, is a potent mitogen for cultured dog tracheal smooth muscle cells. Am J Respir Cell Mol Biol 1995; 13: 227-236.

146 Brown JK, Jones CA, Rooney LA, et al. Mast cell tryptase activates extracellular-regulated kinases (p44/p42) in airway smooth-muscle cells: importance of proteolytic events, time course, and role in mediating mitogenesis. Am J Respir Cell Mol Biol 2001; 24: 146-154.

147 Berger P, Tunon-De-Lara JM, Savineau JP, et al. Selected contribution: tryptase-induced PAR-2-mediated $\mathrm{Ca}^{2+}$ signaling in human airway smooth muscle cells. J Appl Physiol 2001; 91: 995-1003.

148 Berger P, Perng DW, Thabrew H, et al. Tryptase and agonists of PAR-2 induce the proliferation of human airway smooth muscle cells. J Appl Physiol 2001; 91: 1372-1379.

149 Brown JK, Hollenberg MD, Jones CA. Tryptase activates phosphatidylinositol 3-kinases proteolytically independent from proteinase activated receptor-2 in cultured dog airway smooth muscle cells. Am J Physiol Lung Cell Mol Physiol 2006; 290: L259-L269.

150 Mullan CS, Riley M, Clarke D, et al. Beta-tryptase regulates IL-8 expression in airway smooth muscle cells by a PAR-2-independent mechanism. Am J Respir Cell Mol Biol 2008; 38: 600-608.

151 Berger P, Girodet PO, Begueret H, et al. Tryptase-stimulated human airway smooth muscle cells induce cytokine synthesis and mast cell chemotaxis. FASEB J 2003; 17: 2139-2141.

152 Chhabra J, Li YZ, Alkhouri H, et al. Histamine and tryptase modulate asthmatic airway smooth muscle GM-CSF and RANTES release. Eur Respir J 2007; 29: 861-870. 
Tatler AL, Porte J, Knox A, et al. Tryptase activates TGFbeta in human airway smooth muscle cells via direct proteolysis. Biochem Biophys Res Commun 2008; 370: 239-242.

Woodman L, Siddiqui S, Cruse G, et al. Mast cells promote airway smooth muscle cell differentiation via autocrine up-regulation of TGF-beta 1. J Immunol 2008; 181: 5001-5007.

Chen H, Xu Y, Yang G, et al. Mast cell chymase promotes hypertrophic scar fibroblast proliferation and collagen synthesis by activating TGF-beta1/Smads signaling pathway. Exp Ther Med 2017; 14: 4438-4442.

Lang YD, Chang SF, Wang LF, et al. Chymase mediates paraquat-induced collagen production in human lung fibroblasts. Toxicol Lett 2010; 193: 19-25.

Zhao XY, Zhao LY, Zheng QS, et al. Chymase induces profibrotic response via transforming growth factor- $\beta_{1} /$ Smad activation in rat cardiac fibroblasts. Mol Cell Biochem 2008; 310: 159-166.

Fu L, Wei CC, Powell PC, et al. Increased fibroblast chymase production mediates procollagen autophagic digestion in volume overload. J Mol Cell Cardiol 2016; 92: 1-9.

pathways in synergistic responses. Am J Physiol 1992; 262: L528-L534.

Albrecht M, Frungieri MB, Kunz L, et al. Divergent effects of the major mast cell products histamine, tryptase and TNF-alpha on human fibroblast behaviour. Cell Mol Life Sci 2005; 62: 2867-2876.

Ruoss SJ, Hartmann T, Caughey GH. Mast cell tryptase is a mitogen for cultured fibroblasts. J Clin Invest 1991; 88: 493-499.

Gruber BL, Kew RR, Jelaska A, et al. Human mast cells activate fibroblasts: tryptase is a fibrogenic factor stimulating collagen messenger ribonucleic acid synthesis and fibroblast chemotaxis. J Immunol 1997; 158: 2310-2317.

Cairns JA, Walls AF. Mast cell tryptase stimulates the synthesis of type I collagen in human lung fibroblasts. J Clin Invest 1997; 99: 1313-1321.

Abe M, Kurosawa M, Ishikawa $\mathrm{O}$, et al. Mast cell tryptase stimulates both human dermal fibroblast proliferation and type I collagen production. Clin Exp Allergy 1998; 28: 1509-1517.

Akers IA, Parsons M, Hill MR, et al. Mast cell tryptase stimulates human lung fibroblast proliferation via protease-activated receptor-2. Am J Physiol Lung Cell Mol Physiol 2000; 278: L193-L201.

Frungieri MB, Weidinger S, Meineke V, et al. Proliferative action of mast-cell tryptase is mediated by PAR2, COX2, prostaglandins, and PPARgamma: possible relevance to human fibrotic disorders. Proc Natl Acad Sci USA 2002; 99: 15072-15077.

McLarty JL, Melendez GC, Brower GL, et al. Tryptase/protease-activated receptor 2 interactions induce selective mitogen-activated protein kinase signaling and collagen synthesis by cardiac fibroblasts. Hypertension 2011; 58: 264-270.

Tan H, Chen Z, Chen F, et al. Tryptase promotes the profibrotic phenotype transfer of atrial fibroblasts by PAR2 and PPARgamma pathway. Arch Med Res 2018; 49: 568-575.

Shin K, Nigrovic PA, Crish J, et al. Mast cells contribute to autoimmune inflammatory arthritis via their tryptase/heparin complexes. J Immunol 2009; 182: 647-656.

Bagher M, Larsson-Callerfelt AK, Rosmark O, et al. Mast cells and mast cell tryptase enhance migration of human lung fibroblasts through protease-activated receptor 2. Cell Commun Signal 2018; 16: 59.

Mangia A, Malfettone A, Rossi R, et al. Tissue remodelling in breast cancer: human mast cell tryptase as an initiator of myofibroblast differentiation. Histopathology 2011; 58: 1096-1106.

2 Zhou X, Wei T, Cox CW, et al. Mast cell chymase impairs bronchial epithelium integrity by degrading cell junction molecules of epithelial cells. Allergy 2018; 74: 1266-1276.

Scudamore CL, Jepson MA, Hirst BH, et al. The rat mucosal mast cell chymase, RMCP-II, alters epithelial cell monolayer permeability in association with altered distribution of the tight junction proteins ZO-1 and occludin. Eur J Cell Biol 1998; 75: 321-330.

Ebihara N, Funaki T, Murakami A, et al. Mast cell chymase decreases the barrier function and inhibits the migration of corneal epithelial cells. Curr Eye Res 2005; 30: 1061-1069.

Groschwitz KR, Ahrens R, Osterfeld H, et al. Mast cells regulate homeostatic intestinal epithelial migration and barrier function by a chymase/Mcpt4-dependent mechanism. Proc Natl Acad Sci USA 2009; 106: 22381-22386.

He SH, Zheng J. Stimulation of mucin secretion from human bronchial epithelial cells by mast cell chymase. Acta Pharmacol Sin 2004; 25: 827-832.

Huttunen M, Harvima IT. Mast cell tryptase and chymase in chronic leg ulcers: chymase is potentially destructive to epithelium and is controlled by proteinase inhibitors. Br J Dermatol 2005; 152: 1149-1160.

Ebihara N, Takai S, Miyazaki M, et al. Mast cell chymase induces conjunctival epithelial cell apoptosis by a mechanism involving degradation of fibronectin. Curr Eye Res 2005; 30: 429-435.

Cairns JA, Walls AF. Mast cell tryptase is a mitogen for epithelial cells. Stimulation of IL-8 production and intercellular adhesion molecule-1 expression. J Immunol 1996; 156: 275-283.

Rastogi P, Young DM, McHowat J. Tryptase activates calcium-independent phospholipase $\mathrm{A}_{2}$ and releases $\mathrm{PGE}_{2}$ in airway epithelial cells. Am J Physiol Lung Cell Mol Physiol 2008; 295: L925-L932.

Arai R, Usui-Ouchi A, Ito Y, et al. Effects of secreted mast cell mediators on retinal pigment epithelial cells: focus on mast cell tryptase. Mediators Inflamm 2017; 2017: 3124753.

Chang EH, Lee JH, Zabner J. Tryptase does not alter transepithelial conductance or paracellular permeability in human airway epithelial cells. Am J Rhinol Allergy 2010; 24: 126-128.

32: 183-187.

4 Wilcz-Villega EM, McClean S, O'Sullivan MA. Mast cell tryptase reduces junctional adhesion molecule-A (JAM-A) expression in intestinal epithelial cells: implications for the mechanisms of barrier dysfunction in irritable bowel syndrome. Am J Gastroenterol 2013; 108: 1140-1151.

5 Clark JM, Abraham WM, Fishman CE, et al. Tryptase inhibitors block allergen-induced airway and inflammatory responses in allergic sheep. Am J Respir Crit Care Med 1995; 152: 2076-2083.

Sylvin H, Dahlback M, Van Der Ploeg I, et al. The tryptase inhibitor APC-366 reduces the acute airway response to allergen in pigs sensitized to Ascaris suum. Clin Exp Allergy 2002; 32: 967-971.

Krishna MT, Chauhan A, Little L, et al. Inhibition of mast cell tryptase by inhaled APC 366 attenuates allergen-induced late-phase airway obstruction in asthma. J Allergy Clin Immunol 2001; 107: 1039-1045. 
Rice KD, Tanaka RD, Katz BA, et al. Inhibitors of tryptase for the treatment of mast cell-mediated diseases. Curr Pharm Des 1998; 4: 381-396.

189 Burgess LE, Newhouse BJ, Ibrahim P, et al. Potent selective nonpeptidic inhibitors of human lung tryptase. Proc Natl Acad Sci USA 1999; 96: 8348-8352.

190 Schaschke N, Matschiner G, Zettl F, et al. Bivalent inhibition of human beta-tryptase. Chem Biol 2001; 8: 313-327.

191 Wright CD, Havill AM, Middleton SC, et al. Inhibition of allergen-induced pulmonary responses by the selective tryptase inhibitor 1,5-bis-[4-[(3-carbamimidoyl-benzenesulfonylamino)-methyl]-phenoxy]-pentane (AMG-126737). Biochem Pharmacol 1999; 58: 1989-1996.

192 Mori S, Itoh Y, Shinohata R, et al. Nafamostat mesilate is an extremely potent inhibitor of human tryptase. J Pharmacol Sci 2003; 92: 420-423.

193 Chen CL, Wang SD, Zeng ZY, et al. Serine protease inhibitors nafamostat mesilate and gabexate mesilate attenuate allergen-induced airway inflammation and eosinophilia in a murine model of asthma. J Allergy Clin Immunol 2006; 118: 105-112.

194 Ishizaki M, Tanaka H, Kajiwara D, et al. Nafamostat mesilate, a potent serine protease inhibitor, inhibits airway eosinophilic inflammation and airway epithelial remodeling in a murine model of allergic asthma. J Pharmacol Sci 2008; 108: 355-363.

195 Lin CC, Lin LJ, Wang SD, et al. The effect of serine protease inhibitors on airway inflammation in a chronic allergen-induced asthma mouse model. Mediators Inflamm 2014; 2014: 879326.

196 Sutton JC, Bolton SA, Hartl KS, et al. Synthesis and SAR of 4-carboxy-2-azetidinone mechanism-based tryptase inhibitors. Bioorg Med Chem Lett 2002; 12: 3229-3233.

197 Oh SW, Pae CI, Lee DK, et al. Tryptase inhibition blocks airway inflammation in a mouse asthma model. J Immunol 2002; 168: 1992-2000.

198 Costanzo MJ, Yabut SC, Almond HR Jr, et al. Potent, small-molecule inhibitors of human mast cell tryptase. Antiasthmatic action of a dipeptide-based transition-state analogue containing a benzothiazole ketone. $J$ Med Chem 2003; 46: 3865-3876.

199 Maryanoff BE, de Garavilla L, Greco MN, et al. Dual inhibition of cathepsin G and chymase is effective in animal models of pulmonary inflammation. Am J Respir Crit Care Med 2010; 181: 247-253.

200 Ahmad S, Ferrario CM. Chymase inhibitors for the treatment of cardiac diseases: a patent review (2010-2018). Expert Opin Ther Pat 2018; 28: 755-764. 